\title{
Learning Self-Reliance and Responsibility from the Point of View of Existentialism
}

\author{
Mārtiņš Veide Dr. psych., Dr. paed. \\ RISEBA University of Applied Sciences, Latvia \\ martinsw@inbox.lv
}

\begin{abstract}
As a result of the increased amount of information the importance of its independent, critical evaluation is increasing, so that the knowledge learning would not be replaced by the accumulation of information. The responsibility for and the ability to evaluate information independently are relevant as learning outcomes of education for sustainable development. Responsibility and self-reliance as important areas of human life are the focus areas of the existentialist approach; still, this approach is very little used in pedagogy. The results of this research substantiate the topicality of the existentialist approach in modern humanistic pedagogy, in which the emphasis is placed on the personal significance of the learning process. The main aim of the article is to analyse the learning of self-reliance and responsibility from the point of view of existentialism and to evaluate the conditions of its realization in pedagogical practice. The study was done by combining the results of the author's previous empirical research, observations in pedagogical practice and analysis of the scientific literature. In the minds of Latvian adults, their self-reliance and responsibility are integral components of both the quality of living and the meaning of learning. With age, there is a growing tendency to associate self-reliance not with independent thinking, but with independence and, consequently, existential concerns about the possibility of its realization. An important existential aspect of the learning process is: the distinction between learning to be self-reliant and responsible and learning to find a place in the network and function in pursuit of personal safety and worth. Self-reliance as a relative independence from security, belongingness and recognition and responsibility as an awareness of one's impulses, feelings and attitudes are related to the survival of existential loneliness and overcoming anxiety. Learning self-reliance and responsibility means learning self-reflection, learning to meet oneself, getting to know one's interests and the factors that cause fear, rather than diverting attention to others to information that helps to justify oneself.
\end{abstract}

Keywords: self-reliance, responsibility, experience, existentialism, sustainable development, adult education.

\section{Introduction}

In the first decades of the $21^{\text {st }}$ century, there is a debate about the amount of information generated daily in comparison to the amount of information generated from the dawn of civilization to the last century, but everyone is certain that it's being produced increasingly quickly (Flint, 2011). However, information as a form of signs or signals that express a message or represent meaning is not yet knowledge, which is a wisdom that can be used in different contexts. In fact, information obtained without personal subjective experience creates the illusion of the existence of knowledge. Daily one can observe how people who try to obtain as much information as possible are exposed to the "universal truth" created by the media - how one needs to correctly behave, dress, think, etc. Despite the fact that such a "universal truth" distances one from oneself, from one's self-awareness, in the spirit of the enlightenment effort of classical philosophy, it is still practiced in schools as knowledge learning. Furthermore, learning of universal examples often occurs outside school - publicly communicated media assessments tend to attract the audience more strongly than academic findings in educational institutions. The study of media literacy in the education curriculum in Latvia concludes that the skill to find information in different sources and the skill to analyse the obtained information are purposefully developed in the expected learning outcomes. The development of the skills of evaluating the credibility of the obtained information, however, is little paid attention to (Andersone, Helmane, 2019, 15). However, the ability to evaluate information independently, critically, is relevant in the context of sustainable development. Education for sustainable development envisages such learning outcomes as critical and systemic thinking and a sense of responsibility (What is Education..., 2020).

The students themselves want a supportive and understanding teacher, they want a creative learning environment in the classroom, but at the same time they are reluctant to take responsibility for their own learning activities. In their practice, Latvian pedagogues have faced a problem - when learners "get stuck" 
on a type of task or problem, or a question, they do not seek for new, innovative and creative solutions to problems in the study process. Even if the study subject is mainly based on the development of creative thinking, pedagogical practice reveals that pupils still often choose the easiest solution - the imitation of a teacher (Marcenko, Dislere, 2017, 367). Clearly, the teacher still has to confront inert ideas in the formal education system. This formal education is discovered to be cognitively oriented and neglecting other essential dimensions of human life (Badjanova, Ilisko, 2014, 27). The methodology of this system contains answers that the students repeat without deliberation. The passed exams and the received grades, in turn, convince the students that they really know and understand what is important and, hence, encourage them to think that they themselves are important. As a result, the educated are well informed, but have lost the ability to think independently.

In the 20th century, an anthropological direction has been marked in Western philosophy, which is characterized by the liberation from ideology, prejudices, idols and previously given meanings. This direction is most fully represented by existentialism, for which the liberation of human creative potential and existence is important. Unlike other philosophical concepts in existentialism, human existence is before essence - there is no human nature, no absolute essence (Sartre, 2018). One cannot live life according to an example given to the species as in the animal world, one must live on their own. Such a state of being thrown into the world makes a person feel insecure and constantly look for ideals, some "absolute", to which one can attach to. Historically, people have often succumbed to ideologies that have strong authority or high numerical support. Nevertheless, the submission of one's mind to an ideology does not bring complete inner peace and satisfaction. Thus, a human being is the only "animal" whose existence poses problems that one needs to resolve, and which cannot be avoided (Fromm, 2013). Any achievements are enjoyed only for a short time; thereafter, the dichotomy created by one's mind makes one feel dissatisfied again and look for new solutions, new achievements. To develop and shape one's world in which one can feel in accordance with oneself, it is subjected to such existential dichotomies as life and death, independence and dependence, responsibility and destiny. Although resolving contradictions is the basis for creativity, education based on Aristotelian logic encourages people to strive for non-contradiction in their daily lives.

The existentialist approach focuses on important areas of human life such as freedom, responsibility, selfreliance, the meaning of life and death, but this approach is still very little used in pedagogy. Hence, the author puts forward the aim of the study: to analyse the learning of self-reliance and responsibility from the point of view of existentialism and to evaluate the conditions of its realization in pedagogical practice.

\section{Methodology}

This study is based on:

- the results of three empirical studies in which the perceptions of Latvian students (aged 20-24) and seniors (aged 70 years or more) on the sense of learning and on the quality of life, its contributing and restrictive aspects (Veide, 2016; Veide, 2018; Veide, 2019) have been clarified;

- the analysis of scientific literature - for the research methodological basis choosing existentialism (Heidegger, 2010; Jaspers, 1999; Kierkegaard, 2013; Sartre, 2003, 2007, 2018) and findings of humanistic and existential psychology authors (Allport, 1960; Fromm, 2013; Maslow, 2013, Yalom, 2020);

- the observations by the author himself in his pedagogical practice.

The data will be used to answer two practical research questions. 1. What is the understanding of selfreliance and responsibility by adults, and what is the role of existential aspects in it? 2. What promotes and what limits the learning of self-reliance and responsibility nowadays in society? The next part of this article is structured according to these questions.

\section{Results and Discussions}

1. One can notice that in social networks many young Latvian people like to write down "school of life" as one of the educational institutions they have attended to. This indicates the importance of one's own life experience. However, as everyone has their own personal experience, such experience does not yield to any of the patterned assessments required by the education system. The philosophy of life that predates existentialism includes life experiences and feelings in an organized list of sciences of mind 
(Geisteswissenschaften). According to W. Dilthey life experience is the skeleton of our existence, representative and comprehensive knowledge (Dilthey, Makkreel, Rodi, 2010). This knowledge cannot be the same for everyone since everyone has their own physical and mental preconditions and the events experienced are also different. The objectivity of W. Dilthey's sciences of mind is to be found in the knowledge that requires absolute subjective experience. Existentialism continues to emphasize the importance of subjective experience, linking it to independent choice and responsibility. Nowadays educators define existentialism as a belief that is focused on a personal, subjective experience where the world of choice and responsibility are primary (Webb, Metha, Jordan, 2017, 424).

In any field that can be learned within the curriculum, specialists and analysts define concepts, create categories, classifications and schemes. However, following specialists and agreeing with scientists, the student only explains and develops their theories, their dogmas, their knowledge, still not understanding oneself - what one is learning. To understand oneself, society and the world, to become a self-reliant, capable personality, of course, one may need help, suggestion and some scale. However, no other human theory, whatever it may be, can replace one's personal experience. The idea that mentioning something does not yet mean knowing, but to know one needs to experience it first, is not new. This is one of the basic postulates of Gnostics about cognition. In the dialogue "State" Plato has described the essence of the learning process by comparing the attempt to put knowledge into the human soul to the attempt of making one who was born blind (Plato, 2016, 197). B. Fülgraff refers to education in general, mentioning that education is always a person's own activity: "I cannot be educated, I can only educate myself" (Fülgraff, 1993, 79).

Subjective experience and self-reliance are also determinants of a sense of life quality. Empirical research shows that the most important condition for life quality in the minds of the Latvian population is the person oneself with own personality traits, such as: ability to live in harmony with oneself and loved ones and selfreliance (Kalvans, 2013; Veide, 2016; Veide, 2019). In terms of content, two different interpretations can be found regarding the topicality of self-reliance - it can be independence in judgments, i.e., independence from public opinion and adherence to one's own beliefs (more often relevant for young people) and independence from peers (relatively more often relevant for seniors). Since the ontological basis of human existence is in temporality, in the finality of man, time becomes an important characteristic of one's existence. The understanding of self-reliance as independence alternates with the issue of time, which is one of the most frequently mentioned limitations of life quality. For young people, who strive to "stand on their own feet" and become independent of their parents, time is lost and never sufficient, while seniors are increasingly worried to become dependent on carers as a result of the lost time (past "years of strength"). A condition of life quality such as health in the minds of seniors is also important because it enables them to be independent from others, i.e., to take care of oneself (Veide, 2019). The most common learning goal in the minds of both students and seniors is self-improvement, self-development, and it is largely influenced by the dictates of time, i.e., learning to develop oneself in order "not to lag behind". Important quality of self-development, which one already has, or one is still mastering, is the achieved self-reliance and responsibility, the ability to deal with one's emotions. For seniors it is mainly: learning to be honest. It points to a deeper understanding of one's responsibilities that come with experience acquired over a longer period of time - "what you sow is what you will reap". However, even when thinking about the meaning of learning, self-reliance is quite often understood simply as independence - "so as not to obey anyone" (Veide, 2018).

In glossaries of terms, self-reliance is also explained as independence from others, as the ability to exist without the help of others. However, it can be seen that no one is and cannot be completely independent. No one can even breathe independently of what is around them (for example, plants, which, unlike humans, "inhale" nitrogen and "exhale" oxygen) and what is happening at this moment (for example, from lung function and the factors that have a continuous impact on it). Nevertheless, the illusion of independence is widespread. People tend to emphasize their independence in communication with each other, for example, independence from smoking, computer games, parents and members of the other gender. Independence is also proclaimed as something positive on a national scale - it is celebrated as a holiday. Seemingly, this is because one's independence from something is an essential component of one's "positive" self-image. Seeing the illusoriness of one's independence would mean losing one's self-image, which would be like death, because what is considered one would actually die. 
In the pedagogical process, it makes sense to talk about self-reliance as a relative independence from the social environment - as far as the individual's needs for belongingness, recognition and security are concerned, which can only be met with the participation of other people, i.e., only from the outside. The fact that the individual different has to fight for oneself in the social sphere is already described in J.J. Rousseau's works (Rousseau, 2016; Rousseau, 2008). In the $20^{\text {th }}$ century the submission of an individual to society that forces one to live according to the established norms is noted by existentialists who postulate that in fact it is not the society that creates an individual but the society itself arises from individuals who chose who they want to be and chose what a person should be like in general (Sartre, 2003, 260). Nevertheless, nowadays a human being often does not choose oneself but a function and own belongingness. When deciding how to best deal with a certain situation, one bases its decisions on the principles postulated by the authorities, the rules of conduct set by an institution, or the judgment of another person (either a friend or a world-famous and financially successful footballer, or a fashion designer). The apparent "self-reliance" manifests itself only in the independent choice of one of the aforementioned examples. Such "self-reliance" is safer because it promotes adaptation and belongingness to the social environment. There is, however, a fundamental difference between independent and adaptive activity - the former serves individualization, the latter - tribalism (Allport, 1960, 34). A self-reliant person may not have adapted to the social environment and culture, but is certainly not a conformist.

The ideas of existentialism contribute to solving the issues related to responsibility in pedagogy. J.P. Sartre has pointed out that responsibility is a need that trivially stems from our freedom (Sartre, 2018). It can be noted that almost any religion offers rules by which death can be avoided. Such rules not only provide comfort when anxiety about one's disappearance is felt, but also authority - religion seems to take responsibility for the individual. It "saves" a person from a frightening confrontation with own personal freedom. However, this does not mean that the possibility of transferring responsibility for one's own life is only possible in religious schools. Atheism disputes the existence of God, but not the notion that the essence - the once-given, ready-made nature of man - precedes existence. If this is the case, then the scientist, as the expressor of the mysteries of the universe, in a logical form becomes entitled to think in place of other members of society and "enlighten" them. Since the beginning of modern culture, such tendencies of spiritual guardianship have appeared in many fields, such as psychology, philosophy, politics, ethics, and especially pedagogy. In the world of science, the message "scientists have discovered that..." becomes a truly relieving message of joy to an individual fleeing from one's own freedom and responsibility.

Adults' understanding of responsibility is reflected in their pedagogical attitude towards children. By participating in the promotion of the child's development with the most noble goals, the adult forms the child's personality in accordance with the own idea of the expected improvements. In fact, such a parent or educator is driven by an interest in what the child should become, rather than an interest in the sometimes difficult-tounderstand personality that the child already is. The ideal becomes more important than the existence itself. In turn, any discrepancy with the desired ideal first causes internal dissatisfaction, and then leads to the search for the culprit outside - "bad educators", "frivolous parents", "wrong education system", "uneducated children". It is based on mixing responsibility with duty and the idea that one person may be responsible for another. If there are no rules, no pregiven values and ideals to strive for, then nothing in this world has any meaning other than what the individual has given oneself. Then everything that exists in own life is selfcreated, and no one else can take responsibility for it. The only remaining thing is to realize it. It is unlikely that an educator's selfish intent would be found if he or she tried to help students become aware of themselves in the learning process. However, such an awareness of the construction of one's essence and one's responsibility is frightening. This awareness is subjectively experienced as emptiness as a loss of foundation (groundlessness). Human responsibility is associated with existential oneness, which is felt as a separation not only from other people, but also from the world as it is usually perceived. Existentialists note this basic anxiety of groundlessness as even deeper and more profound than the fear of death (Yalom, 2020). That is why many people, since childhood, are looking for something bigger, more grandiose than themselves - a type of structure or authority. And the education system as a grandiose structure provides such an authority. The accumulation and systematization of information, often referred to as education, actually offers the student a refined way of fleeing from oneself. In this connection, J.P. Sartre points out the inherent anxieties and the feeling of abandonment (Sartre, 2007). Abandonment is linked to the fact that in the absence of any pregiven a priori moral values and instructions, nothing can justify human action. Man has not created oneself; one has been thrown into the world and yet he / she is responsible for everything one does. One is doomed, "the 
condemned" to be free. Concerns, in turn, are related to responsibility for one's choices. A person who decides something and is aware that he / she chooses not only own existence but also all humanity cannot escape a deep sense of responsibility. Those who feel that they are not worried hide these feelings, run away from them. Worries do not disappear if they are hidden. S. Kierkegaard compares these worries with Abraham's worries, referring to the test of Abraham described in the Old Testament (Genesis, 22.), in which God makes him sacrifice his only son (Kierkegaard, 2013,37). If I hear a voice, then only I can decide if that is an angel's voice. If I consider an action to be good, it is I, and not someone else, who decides that it is good, not evil.

2. There is a paradox in students' perceptions of learning: in their opinion, it makes sense to self-develop, to become more self-reliant and, at the same time, to adapt (Veide, 2018). This is due to the fact that self-reliant students understand not critical thinking but the widely proclaimed and positively valued independence. Primarily for students this is independence from their parents. This independence also means the opportunity to better integrate into society, i.e., to adapt and to meet the need for belongingness. At the same time, students experience doubts about the meaning of learning. Young people are solving a dilemma: to adapt to the accepted beliefs in society about the need to achieve economic success in the light of competition or to maintain self-reliance by clarifying one's personal meaning in the learning process. Emotionally, this dilemma is accompanied by the fear of losing. However, self-reliance is directly related to the loss, starting with the very first experience, which is acquired with the loss of the mother's physical closeness. Similar to the loss of a safe environment at the moment of birth, also later in life the loss of security is a cost for the possibility of further development. In this way, the readiness to lose, to fail, the readiness to accept insecurity, loneliness and denial bring people closer to self-reliance. On the contrary, the fear of losing security, belongingness and recognition, which forces one to obey external laws, adapt and orientate to others, distances one from self-reliance. When trying to regain the security once lost, reference groups and social affiliations are still being sought.

Fear of loss and pain hinders new experiences. Research by psychologists shows that in everyday life people spend significantly more effort to escape a loss than to gain something equivalent to the loss (Baumeister et al., 2001). People are happy to accept new ideas, adapting them to their existing views. However, they do not want a new experience because it threatens to undermine their beliefs based on their past experience. According to the observation of D.H. Lawrence, "the world fears a new experience more than it fears anything. Because a new experience displaces so many old experiences. And it is like trying to use muscles that have perhaps never been used, or that have been going stiff for ages. It hurts horribly" (Lawrence, 2011, 41). Pain stands between a person's experience and one's ability to feel it, live through it, and, therefore, learn from it. Seniors aged 70 years or more, looking back on their lives, tend to note suffering (e.g., sickness, deportation) as important teachers in life lessons, while young people think of learning from a difficult life challenge significantly less often (Veide, 2018). Instead of perceiving pain as a teacher, or as an indicator that something has not yet been understood, one uses pharmaceuticals nowadays to fight against pain. Pain in people's minds has not always been something terrible, as an unfortunate mistake, something that should be changed at all costs. In earlier ages, people have been able to see pain as a way to something new, as an important lesson (Rohr, 2017). The free choice to be made at every moment of life, which J.P. Sartre talks about, in this context is the choice between development and security.

Self-reliance as a relative independence from the requirements of the social environment does not mean that one should disregard them or limit communication. External demands can be very well identified and respected, but identified directly as external demands, without confusing them with own interests, responsibilities or the voice of conscience. Getting rid of the attachment to own immediate environment means choosing creativity instead of duplication. When a person stays with oneself, the opportunities to base one's attitude on the patterns of the immediate environment disappear, to take over the existing ones disappear, hence, the only possibility is to re-create. Creativity promotes openness to the world. However, this lack of self-reliance becomes a constraint on sustainable development for today's busy individuals. In the $19^{\text {th }}$ century classical philosophy, creativity is associated with reflection - the creative mind follows the setting: "Observe and know yourself!" Respectively, the development of one's mind is achieved by establishing a self-observing view of one's life. This self-reflection of the cognitive mind is like a conscience that gradually replaces confession in pedagogic theories from the $19^{\text {th }}$ century onwards. For example, in the pedagogical literature of the early $20^{\text {th }}$ century, following conscience is mentioned as a necessary condition for a person not to contradict oneself (Hessens, 1929, 71). Today, 
on the other hand, confession and conscience are being replaced by admissions. Moreover, if confession to a religious person seems necessary for organizing one's life, and if the conscience of a secular person is an inseparable inner voice, then admission to a modern person might seem like a fall - mainly due to external reasons. Confession does not seem necessary; it is rather associated with a loss. Modern philosophers have found that the postclassical age has opened the human being up to the market, information, sexual relations, but closed one to deep thoughts, reflection and justice (Kule, 2006, 103). Reflection of mind, deep thoughts or listening to one's conscious occurs in a solitary meeting with oneself. However, this meeting is not pleasant because it makes one feel one's loneliness, insignificance and powerlessness in the face of old age and death. Therefore, the individual tries to focus all attention on the outside - on the market relationships and on information that would help one to justify oneself.

Turning one's attention from oneself to others is related to responsibility. If the educator believes that he/she is responsible for the student's learning, then the educator automatically activates a motive, the satisfaction of which is linked to the student. Responsibility becomes an obligation - the teacher needs the student to learn. Unknowingly, the teacher has created a dependence on the student. The teacher is no longer free. His / her passion and enthusiasm become dependent on the external social environment. The educator is now able to feel excited about the own work only if the student achieves certain results or is excited about the pedagogue. The teacher can no longer like the student as such - as a personality. The teacher becomes able to feel sympathy for the student only in response to the student's sympathy for him / her. Similarly, a student who has started studying with a real interest and joy of cognition loses it over time, increasingly often thinking about the study work as a duty. In pursuit of one's significance, all life - even waking up in the morning, can become a duty that has to be done as if by force. In this way, both taking responsibility for one's own experiences and life satisfaction are suppressed.

In a social environment where there is a perception that one person's responsibility for another is possible, it is almost impossible to expect its development in children. To protect their children, adults often make choices for their children. There is no denying that in this way they are actually taking real significant security measures. However, without personal choice, due to the lack of independent decisions, a person (at any age) loses faith in oneself, moves away from own impulses and feelings, from own attitude to everything, dissolves own personal motives in generally accepted standards. In addition, adults, who to help and support students, carry out their homework on their behalf, actually teach them that it is acceptable to show someone else's work as own and that it is more important to gain external satisfaction (good marks and praise from the teacher) than to understand the meaning and learn by essence. Independence from the social environment is characteristic for self-actualized people, who are happy to think alone and submit mainly to their own internal determinants and not to those of other people or society (Maslow, 2013). Greater internal independence from the point of view of others is associated with less fear of others and, consequently, less hostility towards them. Self-reliance manifests itself in not caring about receiving prestige, awards, honours, praise or positive evaluation. In this way, a system that expects that pupils or students pursuit for good grades does not promote the development of self-reliance. On the other hand, the education system based on the scheme of operant behaviour does not work in the case of an independent self-actualized individual, because the activity of a self-reliant person is not so much determined by external as internal stimuli.

Responsibility, like guilt, is a consequence of self-confidence, i.e., one's self-awareness. A person is guilty not only of crimes against other people, not only of violating moral or social laws, but also of crimes against oneself. According to M. Heidegger: being guilty also has the signification of "being responsible for" that is, being the cause or author of something, or even being the occasion for something (Heidegger, 2010,282). A person is responsible not when one thinks that he / she owes someone or feels guilty in front of someone, but when one is aware of oneself. It can be said that from the point of existentialism learning to be responsible means learning to live in the present (Jaspers, 1999, 65). When an individual does not lose oneself in the past or the future, one begins to realize own responsibility in everyday life - for own impulses and feelings, for own lifestyle and aspirations, for own attitude towards other people, for own closeness or distance with them, for all small and large decisions that are important not only for oneself but also for the historical course of events. Responsibility learning is also about daring to ask important (existential) questions, given that the answer may not coincide with the goals of one's ego or that one has to wait a long time for it. Therefore, it is adequate to rely on the desired 
outcome within the limits of own activities, but not on other people, because they are also free (in their choice at every moment). J.P. Sartre calls it action without hope. Hope is always based on desires and fears. So acting without hope means, firstly, acknowledging one's interests and, secondly, not succumbing to one's fears. Losing the last hope can become a cause not only for depression, but also to start a fuller, more authentic and responsible life. Dante's inscription at the gate of "The city of woe": "All hope abandon ye who enter here" can be difficult to accept. However, it can be perceived not as a curse, but as a blessing: getting rid of the future possibilities that bring suffering allows one to finally start living in the present that K. Jaspers writes about, and takes responsibility. When choosing to take responsibility for one's current experience, one uses this experience in a constructive way - to learn.

\section{Conclusions}

- Both young people's perceptions of life quality and their perceptions of the meaning of learning show the importance of their self-reliance. At the same time, they show existential concerns about the possibility of its realization to the extent that self-reliance is interpreted as independence from others. As such concerns are more common in the senior group, it can be concluded that over the years, the tendency to associate self-reliance not with critical thinking, but with independence increases. This, in turn, indicates the topicality of examining self-reliance and the interpretation of its learning.

- In pedagogy, self-reliance should be seen as self-actualized person's relative independence from the social environment - as far as the individual's needs for security, belongingness and recognition are concerned, which can only be met with the participation of other people. Thus, it may take the form of not caring about receiving a positive evaluation (good grades).

- Learning from the point of view of existentialism means not so much an external activity as an internal one. Learning from this point of view is not the acquisition of the right knowledge and methods, but a contemplative and self-directed experience. From the point of view of existentialism, what hinders sustainable development is basically the attractiveness of the idea of security - a desire to protect oneself from the threat of possible pain and loss. It is important for the educator to see and understand not only the development and its benefits, but also the fear of development.

- Responsibility is associated with the experience of existential loneliness and overcoming anxiety. Learning responsibility is mainly hampered by confusing it with duty and the idea that one person may be responsible for another. A person is responsible not when one thinks that he / she owes someone or is afraid of becoming guilty in front of someone, but when one is aware of own impulses, feelings and attitudes.

- There is an internal struggle in young people's perceptions of learning: to adapt to public perceptions of the need for economic success in a competitive environment or to maintain selfreliance by clarifying their own personal meaning in the learning process. In this context, the following existential aspects of the learning process should be considered as important: 1) distinguishing between learning to be self-reliant and responsible for learning to find a place in the network and to function in pursuit of personal security and benefits, 2) the opportunity and the courage to doubt and ask.

- Willingness to accept insecurity, loneliness and even denial, which results in less fear of others and thus communication becomes freer and more open, which in turn promotes a willingness to cooperate and collaborative decision-making, brings people closer to self-reliance.

- Learning self-reliance and responsibility means learning self-reflection, learning to meet oneself, getting to know one's own interests and factors that cause fear, and not to divert own attention from oneself to others, to information that would help to justify oneself. In turn, meeting oneself is related to raising existential questions that are important to oneself, the answers to which can be obtained only through conscious subjective experience.

\section{Bibliography}

1. Allport G.W. (1960). Becoming: basic considerations for a psychology of personality. Yale University Press

2. Andersone R., Helmane I. (2019). Towards Media Literacy in the Education Curriculum: Experience of Latvia. In V. Dislere (Ed.), The Proceedings of the International Scientific Conference Rural 
Environment. Education. Personality (REEP), 12. Jelgava: Latvia University of Life Sciences and Technologies, 15-21. doi: 10.22616/REEP.2019.001

3. Badjanova J., Ilisko Dz. (2014). Holistic philosophy based teaching approaches in Latvian primary schools: Primary education teachers' view. In V. Dislere (Ed.), The Proceedings of the International Scientific Conference Rural Environment. Education. Personality (REEP), 7. Jelgava: LLU, 22-28. Retrieved from https://llufb.llu.lv/conference/REEP/2014/Latvia-Univ-Agricult-REEP-

2014proceedings-22-28.pdf

4. Baumeister R.F., Bratslavsky E., Finkenauer C., Vohs K.D. (2001). Bad is stronger than good. Review of General Psychology, 5(4), 323-370. doi: 10.1037/1089-2680.5.4.323

5. Dilthey W., Makkreel R.A. (Ed.), Rodi F. (Ed.). (2010). Wilhelm Dilthey: Selected Works, Volume III: The Formation of the Historical World in the Human Sciences. Princeton University Press.

6. Flint K. (2011). Was Eric Schmidt wrong about the historical scale of the Internet? Retrieved from https://readwrite.com/2011/02/07/are-we-really-creating-as-much/

7. Fromm E. (2013). Man for himself. An Inquiry Into the Psychology of Ethics. Open Road Media

8. Fülgraff B. (1993). Bildung der Generationen [Education of the Generations]. In G. Böhme (Ed.) Zeit haben und Zeit finden. Vorträge der Gerontologischen Tage 1991 und 1992 der Universität des 3. Lebensalters. Idstein: Schulz-Kirchner. (in German)

9. Heidegger M. (2010). Being and time. Albany: State University of New York Press.

10. Hessens S. (1929). Paidagogikas pamati: ievads lietäjamā filizofijā [Fundamentals of Pedagogy: introduction to philosophy-in-use]. Riga: O. Berga izdevniecība. (In Latvian)

11. Jaspers K. (1999). Was ist Erziehung? Ein Lesebuch [What is education? A reading book]. München: Piper. (in German)

12. Kalvans E. (2013). Latgales iedzìvotāju laimes izjūtas struktūra un psihologiskēas labklājības saturs [The Structure of Latgale Inhabitants' Feeling of Happiness and Content of Psychological Well-Being]. (Doctoral Thesis, Daugavpils University, Daugavpils, Latvia). (in Latvian)

13. Kierkegaard S. (2013). Fear and trembling and the sickness unto death. Princeton University Press.

14. Kule M. (2006). Eirodzīve [European life]. Rīga: LU FSI. (in Latvian)

15. Lawrence D.H. (2011). Studies in Classical American Literature. London: Shearsman Books.

16. Marcenko G., Dislere V. (2017). Thinking of pupils in the lessons of home economics and technologies. In V. Dislere (Ed.), The Proceedings of the International Scientific Conference Rural Environment. Education. Personality (REEP), 10. Jelgava: LLU, 367-375. Retrieved from https://lufb.llu.lv/conference/REEP/2017/Latvia-Univ-Agricult-REEP-2017_proceedings-367-375.pdf

17. Maslow A.H. (2013). Toward a psychology of being ( $3^{\text {rd }}$ ed.). Start Publishing LLC (Kindle edition).

18. Plato. (2016). The republic of Plato. New York: Basic Books.

19. Rohr R. (2017). Adam's return: the five promises of male initiation. Crossroad.

20. Rousseau J.J. (2008). The confessions. Oxford University Press.

21. Rousseau J.J. (2016). Emile: or concerning education. CreateSpace Independent Publishing.

22. Sartre J.P. (2003). Existentialism. In L.E. Cahoone (Ed.), From modernism to postmodernism: an anthology $\left(2^{\text {nd }}\right.$ ed.). Willey-Blackwell Publishers, 259-273.

23. Sartre J.P. (2007). Existentialism is a humanism. Yale University Press.

24. Sartre J.P. (2018). Being and Nothingness. An Essay in Phenomenological Ontology Routledge.

25. Veide M. (2016). The understanding of life quality by students nowadays. In V. Dislere (Ed.), The Proceedings of the International Scientific Conference Rural Environment. Education. Personality (REEP), 9. Jelgava: LLU, 187-194. Retrieved from https://lufb.llu.lv/conference/REEP/2016/Latvia-Univ-Agricult-REEP2016proceed2255-808X-187-194.pdf

26. Veide M. (2018). The understanding of the learning sense by students and seniors nowadays. In L. Daniela (Ed.), The Proceedings of ATEE Spring Conference Innovations, Technologies and Research in Education. Cambridge Scholars Publishing, 338-356.

27. Veide M. (2019). The understanding of life quality by Latvian seniors nowadays. In V. Dislere (Ed.), The Proceedings of the International Scientific Conference Rural Environment. Education. Personality (REEP), 12. Jelgava: Latvia University of Life Sciences and Technologies, 231-238. doi: 10.22616/REEP.2019.030

28. Webb L.D., Metha A., Jordan K.F. (2017). Foundations of American education (8 $8^{\text {th }}$ ed.). Pearson.

29. What is Education for Sustainable Development? (2020). United Nations Educational, Scientific and Cultural Organization (UNESCO). Retrieved from https://en.unesco.org/themes/educationsustainable-development/what-is-esd

30. Yalom I.D. (2020). Existential psychotherapy. Basic Books. 